\title{
Physicians can justifiably euthanize certain severely impaired neonates
}

\author{
Udo Schuklenk, $\mathrm{PhD}$
}

See related articles on page 532 and pages 533-4.

Clinicians in a scenario involving a neonate with heterotaxy syndrome would not have included euthanasia as an option for the parents had they believed surgical procedures would likely be successful and permit the infant to live a reasonably healthy life.

Legislators in the jurisdiction where the case scenario played out concluded that there are circumstances where infanticide is morally acceptable. They legislated that physician-assisted death be made available in their jurisdiction for certain severely impaired neonates, including apparently the infant under consideration. A majority of practicing neonatologists in Europe concurs that intensive care is only acceptable if it will result not merely in the survival of an infant but also in an acceptable future quality of life. ${ }^{1}$ In the United States the President's Commission for the Study of Ethical Problems in Medicine and Biomedical and Behavioral Research also concluded that there can be conditions sufficiently serious "that continued existence would not be a net benefit to the infant.".

There appear to be some cases, then, where continuing existence is not in a severely impaired neonate's best interest. Terminating its life, based on parent choice, seems a prima facie reasonable option.

\section{DISCUSSION}

\section{Infants Lack Decision-Making Capacity}

What makes cases such as this morally circumspect in the eyes of many is that, unlike with competent adults, a neonate has no occurrent capacity to express his reflective wishes. There are no reflective wishes, not even a reflective

\footnotetext{
From the Philosophy Department, Queen's University, Kingston, Ontario, Canada. Supported by the endowment awarded to the Ontario Research Chair in Bioethics and Public Policy. The endowment was provided to Queen's University by the province of Ontario.

Disclosures: Author has nothing to disclose with regard to commercial support. Read at the 94th Annual Meeting of The American Association for Thoracic Surgery, Toronto, Ontario, Canada, April 26-30, 2014.

Received for publication Aug 28, 2014; revisions received Sept 19, 2014; accepted for publication Oct 5, 2014

Address for reprints: Udo Schuklenk, PhD, Philosophy Department, Bader Ln, Watson Hall 309, Kingston, ON, Canada K7L3N6 (E-mail: udo.schuklenk@ gmail.com).

J Thorac Cardiovasc Surg 2015;149:535-7

$0022-5223 / \$ 36.00$

Copyright (c) 2015 by The American Association for Thoracic Surgery

http://dx.doi.org/10.1016/j.jtcvs.2014.10.027
}

interest in continuing existence. Adults facing this infant's life prospects might well decide to ask for assisted dying. They would have been able to gather relevant information and make up their minds on whether or not they would want to live that kind of life. This option is unavailable to the neonate. His parents should be the ones making this difficult decision.

\section{Sanctity of Life Versus Quality of Life}

What is controversial is whether there can be legitimate circumstances where the life of a severely impaired neonate may be actively terminated. For most Christian ethicists this question is relatively easily settled: Human life from the moment of conception is of infinite value, and whereas we are not obliged to go to however-defined extraordinary length to keep such a severely impaired neonate alive, we must not actively end its life. This view has been challenged by many prominent secular ethicists. ${ }^{3}$ They propose an alternative approach to what is also known as the sanctity-of-life doctrine in medicine. ${ }^{4}$ In their view we should replace the sanctity-of-life doctrine with a quality-of-life ethic. ${ }^{5}$

\section{Quality-of-Life Ethic and Infanticide}

A quality-of-life ethic requires us to focus on a neonate's current and future quality of life as relevant decisionmaking criteria. We would ask questions such as: Does this baby have the capacity for development to an extent that will allow him or her to have a life and not merely be alive? ${ }^{6}$ If we reach the conclusion that it would not, we would have reason to conclude that his life is not worth living. Prolonging his life would not be in the infant's best interest. Importantly, in addressing this question we ought to look at the infant's current and future life prospects as well as we can from his own point of view. We are asking questions such as, What is he getting out of his life now and what would he get out of his life if the proposed surgery was successful? Would it be worth it to him?

An objection could be made that we cannot know with certainty what is in such a severely disabled infant's best interest. The President's Commission emphasized that infants have well-being interests, including experiencing pleasure rather than pain and suffering, very much like we do. If we face a situation where an infant's current and future life prospects involve overwhelming pain and suffering we would have a good reason to proactively end his life. The neonate in our case has no capacity or desire to exist now or in the future. In morally important ways his developmental state is closer to that of a fetus than to that 
of a person like you and me. The parents should be able to freely decide on what would amount to postnatal abortion.

\section{Quality-of-Life Ethic and Terminal Sedation}

An objection could be made on the basis that if we are fundamentally concerned about quality of life, why couldn't we decide to forgo the life-prolonging medical interventions and provide instead terminal sedation to the infant? This would permit those opposed to assisted dying to claim that a natural death would occur. In this scenario little or no pain would be experienced by the infant.

The logic behind this solution is based on an unsound kind of reasoning; namely, St Thomas Aquinas' doctrine-of-the-double-effect. ${ }^{7}$ The doctrine states that if you undertake an action where you intend to achieve something desirable (alleviate suffering) and in the process something undesirable occurs (death), you are ethically in the clear as long as you did not intend for the foreseeable death to occur. Typically today a proportionality condition is attached to the doctrine. That is, the undesirable unintended consequence must not outweigh the desirable intended outcome. This is not a plausible account of moral responsibility. We are morally responsible for foreseeable consequences of our actions, whether we intend for those consequences to occur or not. The outcome of this action is no different to an outcome whereby someone proactively terminated the life of a neonate. The doctrine permits doctors to do the right thing-while claiming somewhat disingenuously that they did not quite mean for the foreseeable death to occur. There appears to be some psychological comfort that the doctrine offers to clinicians, but that does not make it any more plausible.

The other reason why this course of action appears to be popular with doctors has to do with another doctrine, the so-called acts and omission doctrine. It holds that there is a moral difference between actively killing a patient and omitting to keep a patient alive. It permits those who have not brought about the death of a patient by actively killing him but by omitting to keep him alive, to feel better about their chosen course of action. However, in our case this distinction isn't plausible either. Here the deliberate omission to act to keep the patient alive leads foreseeably to the death of the patient. The outcome between not acting and omitting to act is exactly the same-except omitting to act delays the inevitable for no good reason.

From a quality-of-life ethic point of view terminal sedation could prima facie be an acceptable option, were it not for the following issues.

\section{Parental and Health Care Professionals' Interests Matter}

If doctors were to terminally sedate the infant he would not suffer any longer, so why terminate his life proactively?
Why then should doctors provide assisted dying on the parents' request?

They should do so because the parents and attending health care professionals' interests matter in morally relevant ways. The unnecessarily prolonged dying of their infant son would extend a severely distressing situation for the parents. They would have to witness the deterioration of their infant son over a period of days, possibly weeks. Some of the attending health care professionals would undoubtedly also find it psychologically difficult to watch the child die foreseeably an unnecessarily slow death. What we ought to enter into the equation are the interests of those involved in the care of the infant. Given that a terminally sedated infant would have no surviving interests to speak of, the interests of these other parties matter. If his prolonged dying is harmful to them, a further quality-of-life based argument in favor of terminating the infant's life is established.

\section{Resource Allocation Justice}

The question of whether it would be a wise allocation of scarce health care resources to undertake the proposed surgical procedures invariably arises in circumstances such as this. Continuing life-prolonging care for the infant would be futile, it would constitute a waste of scarce health care resources. Health care resources ought to be deployed where they can actually benefit patients by improving their quality of life. This cannot be achieved in the scenario under consideration.

\section{Slippery Slope Concerns}

Prenatal testing renders the need for infanticide exceedingly rare. For an indication of how rare such cases are it is worthwhile to look at published evidence from The Netherlands where involuntary euthanasia for severely impaired neonates is legally available. Of about 200,000 children born in The Netherlands on an annual basis only very few newborns saw their lives ended by this means (4 in total between 1995 and 2005, none between 2005 and 2010). ${ }^{8}$ A larger number of impaired neonates' lives are ended by a combination of withdrawing or withholding treatment. Withdrawing treatment almost always entails the withdrawal of artificial nutrition and hydration. These cases still number below 300, decreasing from 299 in 1995 to 177 in 2010. The permissibility of infanticide in The Netherlands has not led that country down a slippery slope to an ever-increasing number of killed impaired neonates. Apparently the doctrine of the double-effect is alive and well even in The Netherlands.

\section{Unfair Discrimination Against the Disabled?}

Does such a policy unfairly discriminate against the disabled? That does not appear to be the case. Assisted dying for impaired infants is not available in all cases of disability. Assisted dying is available only in circumstances 
where continuing medical care would be futile. The available evidence suggests that that is where clinicians and parents draw the line when it comes to infanticide.

\section{Human Dignity}

Opponents of infanticide under the circumstances described in our scenario often argue that such a course of action would violate human dignity. This is not the place to elaborate in-depth on this subject, but arguably such claims are question-begging; they typically assume the truth of what they need to demonstrate. ${ }^{9}$ Human dignity has no clear, universally agreed-upon meaning. A quality-of-life proponent could just as well argue that respect for human dignity demands that the infant's life be terminated on compassionate grounds. Human dignity is mostly a rhetorical cloak for other-more controversial-ideologic convictions. Incidentally, this applies to other types of nonarguments, too. For instance, opponents of infanticide frequently ask whether we would want to live in a society that permitted such a course of action. Proponents could simply reply affirmatively. We would be better served to avoid this kind of rhetoric in public and professional discourse altogether.

\section{CONCLUSIONS}

Once we have concluded that death is what is in the best interest of the infant, it is unreasonable not to bring about this death as painlessly and as much controlled in terms of timing by the parents as is feasible.

The author thanks Suzanne van de Vathorst, MD, Erasmus Medical Centre, The Netherlands, for critical comments on an earlier draft of this paper as well as for assistance with one of the references.

\section{References}

1. Verhagen E, Sauer PJ. The Groningen Protocol—euthanasia in severely il newborns. N Engl J Med. 2005;352:959-62.

2. President's Commission for the Study of Ethical Problems in Medicine and Biomedical and Behavioral Research. Deciding to forego life-sustaining treatment a report on the ethical, medical, and legal issues in treatment decisions. Available at: https://bioethicsarchive.georgetown.edu/pcbe/reports/ past_commissions/deciding_to_forego_tx.pdf. Accessed May 1, 2014

3. Kuhse H. The sanctity-of-life-doctrine in medicine: a critique. Oxford: Oxford University Press; 1987.

4. Singer P. Rethinking life and death. Melbourne, Australia: Text; 1994.

5. Tooley M. Abortion and infanticide. Oxford: Oxford University Press; 1983.

6. Rachels J. The end of life. Oxford: Oxford University Press; 1986.

7. Uniacke S. The doctrine of the double-effect. In: Ashcroft RE, Dawson A, Draper H, McMillan JR, eds. Principles of health care ethics. 2nd ed. Chichester: Wiley; 2007:263-8.

8. van de Vathorst S, Gevers JKM, van der Heide A, Bolt LLE, Cate K. Evaluatie: Regeling centrale deskundigencommissie late zwangerschapsafbreking in een categorie-2 geval en levensbeëindiging bij pasgeborenen [in Dutch]. Available at: http://www.zonmw.nl/uploads/tx_vipublicaties/Evaluatie_Rdc_zalpdef.pdf. Accessed May 1, 2014.

9. Schuklenk U, van Delden JJ, Downie J, McLean SA, Upshur R, Weinstock D End-of-life decision-making in Canada: the report by the Royal Society of Canada Expert Panel on End-of-Life Decision-Making. Bioethics. 2011;25(Suppl 1):38-44. 